\title{
Verdade e caridade: uma nova apologétiea para a Nova Evangelização
}

\section{Truth and charity: a new apology for a New Evangelization}

\section{José Rafael Solano Durán*}

Recebido em: 18/11/2019. Aceito em: 13/12/2019.

Resumo: A mudança dos tempos faz com que a lgreja reveja seus métodos e proponha uma nova forma de evangelizar, sem jamais alterar seu conteúdo. Presente no magistério recente, a Nova Evangelização ganhou importância na vida eclesial por se apresentar como resposta a esta evolução dos tempos. $A$ Igreja, sensível aos sinais da história e das lutas do homem concreto, da mesma forma oferece dentro da proposta da nova evangelização, uma nova apologética, que, fundamentada na verdade e na caridade, deseja ajudar o homem no caminho da beatitude, dotando de sentido suas ações e fortalecendo sua fé. A nova apologética intenta propor uma aproximação mais existencial da verdade de fé ao homem no seu caminho na busca de sentido, evidenciando a necessidade de reconectar o homem a Deus, através, sobretudo, da liturgia, do testemunho de vida e do diálogo entre fé e cultura.

Palavras-chave: Nova Evangelização. Nova Apologética. Verdade. Caridade.

Abstract: The Church immersed in the contemporary world has to review its methods and propose a new way of evangelizing, however it is important to respect the content. The new evangelizing is part of the Magisterium teaching, so the ecclesial life can offer a better proposal nowadays. Sensitive to the signs of the history and struggles of the human being, the Church also offers within the proposal of this new evangelization a new apologetics which is founded on truth and charity, wishing to help the man on the path of beatitude, giving meaning for actions and strengthening the faith. The new apologetics intends to propose a better existential approach to the truth of faith to human being in his search of meaning, highlighting the need to reconnect man with God, specially through the liturgy, the testimony of life and the dialogue between faith and culture.

Keywords: New Evangelization. Apologetic. Truth. Charity.

* Doutor em Teologia (Pontificia Università Gregoriana, Roma, 2004). Mestre em Teologia (Pontificia Università Gregoriana, Roma, 2001). Graduado em Teologia (Pontificia Universidad Javeriana, PUJ, Colômbia, 1995). Professor da Pontifícia Universidade Católica do Paraná, Curitiba.

E-mail: jose.duran@pucpr.br 


\section{Introdução}

A fé é dom de Deus infundida no coração do homem. É uma virtude através da qual o ser humano, pela sua vontade e pela graça, conforma-se a Deus. Toda vida cristã é alimentada pela fé, de forma que a caridade, que nos faz semelhantes a Deus, tem nela seu fundamento. Alimentar a fé do homem, dessa forma, é como fortalecer uma grande árvore nutrindo suas raízes para que se torne cada vez mais viva. Na vida, a fé é a seiva que faz com o homem permaneça em pé mesmo durante as vicissitudes.

No entanto, na sociedade contemporânea, notadamente se percebe uma crescente crise na transmissão da fé, na qual os homens já não se sentem mais tocados pela mensagem evangélica e se distanciam cada vez mais da única verdade libertadora, Jesus Cristo. O homem, peregrino do século XXI, à medida que vai se afastando da fé, permite que um vazio existencial cresça dentro de si, perdendo o sentido da sua vida. Como responder a esse problema? Como a comunidade eclesial, convocada a ser sal da terra e luz do mundo, se posiciona?

A Igreja, atenta às realidades do mundo e chamada a conceder uma resposta salvífica a todos os seus filhos, exorta e oferece aos cristãos a vivência de uma nova evangelização, para que o renovar da fé, anunciada com clareza e frescor, conduza o homem à Verdade. A transmissão da fé de forma restaurada é colocada no centro da reflexão eclesial do magistério recente.

Dentro da nova evangelização, enfatiza-se uma nova face da apologética, como meio de anúncio da verdade cristã, que consiga fazer a mensagem de Jesus Cristo conhecida, compreendida, experimentada e abraçada, estimulando não mais um prélio ideológico em busca de argumentações racionais, mas animando um combate espiritual que promova o Evangelho.

Diante do acima exposto, cabe a esta pesquisa buscar e expor o papel e a relevância de uma nova apologética no contexto da nova evangelização, sobretudo nos ensinamentos dos papas João Paulo II e Bento XVI. Para lograr tal objetivo, procurar-se-á apresentar o que é a nova evangelização, sua constituição e seu papel dentro da Igreja, bem como a elucidação do que é a nova apologética dentro da nova evangelização, partindo da apologética tradicional até sua atualidade, suas inspirações bíblicas e seus fundamentos teológicos. Por fim, a partir das 
orientações do magistério, se observará seus lugares de ação e a forma como deve se dar.

Este trabalho é animado pela crescente necessidade de, modestamente, contribuir na discussão novo movimento apologético a partir da nova evangelização, sobretudo depois da instituição do Pontifício Conselho para a Promoção da Nova Evangelização, por Bento XVI e colocado sob a responsabilidade do Mons. Rino Fisichella, cujas obras constituem um rico referencial para a presente pesquisa.

Hoje, tempos nos quais a fé se encontra diante de interrogações que provém de uma mentalidade cada vez mais ateísta e tecnicista, o presente trabalho espera cooperar na reflexão do modo como a Igreja se apresentará na história e na cultura, com a finalidade de mudá-las, de dar sentido ao homem perdido, por meio da força da verdade e da caridade.

\section{A Nova Evangelização: maravilhar-se novamente}

O cristianismo é sempre grão de mostarda e árvore: nunca é uma árvore já totalmente crescida, que poderia acabar por secar e desaparecer, mas retorna continuamente à situação de semente. Essa imagem, querida e apresentada por Ratzinger ${ }^{1}$, concede luz ao intento desta pesquisa, que gravita ao entorno da esperança, e da certeza, de que no cristianismo há sempre novos começos, e a nova evangelização, com a nova apologética, é um desses.

A Igreja, desde seu princípio até hoje, não deixou de evangelizar: sua missão de anunciar a palavra de Deus jamais foi interrompida e constantemente produziu frutos. Evangelizar é apontar o caminho para a verdade: Jesus Cristo. No esforço de anunciar o nome do único Senhor e Salvador, reconhece-se que ele possui a resposta para o anseio elementar do ser humano, que é ter vida em plenitude. Ele mostra o caminho que leva à vida e, além disso, é o próprio caminho.

Constantemente se comprova a indigência de vida, sobretudo, na sociedade ocidental. Já não mais se conhece um pleno projeto de realização humana e, assim, perde-se aquela felicidade que daí nasce. $\mathrm{O}$ homem do nosso tempo possui um coração que não está em seu pertinente

1 O então cardeal Ratzinger se utiliza deste exemplo na conferência A nova evangelização, pronunciada no Congresso de catequistas e professores de religião, Roma, 10 de dezembro de 2000, e publicada em L'Osservatore Romano, 19 de janeiro de 2001. 
lugar, uma vez que a arte de viver não brota da ciência e do tecnicismo, onde estão depositadas as esperanças de tantos povos, mas surge daquele que é o caminho, a verdade e a vida ${ }^{2}$, o Evangelho encarnado. Cristo é o caminho para a felicidade, e ele se faz conhecido pela evangelização.

A Boa Nova é dedicada para todos, sem exclusões ou preferências, é vivida a cada dia na celebração dos sacramentos e na promoção da justiça e da caridade. A Igreja, evangelizando, concede alegria e caminho, luz e esperança a muitas pessoas. No entanto, um grande número de batizados habituou-se a viver sem a beleza e o bálsamo da evangelização cotidiana, de sempre. Tantos irmãos já não encontram na evangelização a resposta para a pergunta do sentido da vida. É como lembrava G. K. Chesterton: se tem a maravilha, mas não a capacidade de maravilhar-se .

Se nem todos possuem acesso à evangelização permanente, é necessária uma nova evangelização, que seja eficazmente acolhida por aqueles que não encontram o Evangelho nos anúncios já realizados. A perda do referencial evangélico por parte do povo de Deus questiona a cada batizado que se sente responsável pela dilatação do Reino. Qual a resposta que a comunidade eclesial oferece a estes filhos da Igreja que, longe da evangelização permanente, estão caminhando às palpadelas em seus escuros caminhos espirituais?

A nova evangelização é fruto do olhar da Igreja para o presente, com o desejo de conceder uma resposta plena de significado ao homem e aos desafios que se lhe impõe. Como recordou o Papa Bento XVI, a nova evangelização é a "expressão de uma nova generosa abertura ao dom da graça" 4 .

De forma sistemática, a nova evangelização pode ser compreendida como uma nova modalidade da mesma e imutável ordem de Jesus de levar a todos o seu anúncio de salvação. O papa João XXIII evidenciou essa necessidade de novos meios na convocação do Concílio Vaticano II: "O espírito cristão, católico e apostólico do mundo inteiro espera um progresso na penetração doutrinal e na formação das consciências; é necessário que esta doutrina certa e imutável, que deve ser fielmente

2 Jo $14,6$.

3 Chesterton, G. K. Tremendas Trivialidades. Campinas: CEDET, 2012. p. 19.

4 Carta Apostólica em forma de Motu Proprio "Ubicumque et semper", do Sumo Pontífice Bento XVI com a qual se institui o Pontifício Conselho para a Promoção da Nova Evangelização. 21 de setembro de 2010. 
respeitada, seja aprofundada e exposta de forma a responder às exigências do nosso tempo ${ }^{5}$ ".

De forma que é a comunicação da pessoa de Jesus Cristo, redentor da humanidade, a nova evangelização não possui um conteúdo alternativo à evangelização permanente, mas difere no modo com qual a mesma mensagem é anunciada, diante de um contexto totalmente modificado e assinalado por características próprias da contemporaneidade.

A partir disso, Fisichella define a nova evangelização:

[...] Como uma forma mediante a qual o mesmo Evangelho de sempre é anunciado com novo entusiasmo, novas linguagens compreensiveis em uma condição cultural diferente e novas metodologias capazes de transmitir o sentindo profundo que permanece imutável ${ }^{6}$.

A expressão "nova evangelização" não é um achado dos últimos anos, mas surgiu pela primeira vez nas conclusões da III Conferência Geral do Episcopado Latino-americano, em 1979. O documento original em espanhol, falando de novas situações, assim se exprime:

[...] nacen de cambios socio-culturales y requieren uma nueva Evangelización: emigrantes a otros países; grandes aglomeraciones urbanas en el propio país; masas de todo estrato social en precaria situación de fe; grupos expuestos al influjo de las sectas y de las ideologías que no respetan su identidad, confunden y provocan divisiones ${ }^{7}$.

A ideia tomou corpo e se consolidou com o Papa João Paulo II, que tantas vezes se utilizou da expressão, imbuído pelo desejo de realização daquilo que ela significa. Em 1983, no Haiti, aos bispos do CELAM dizia da importância da evangelização naquele país e lembrava que é necessária uma evangelização nova, no entusiasmo, no método e na expressão ${ }^{8}$.

5 JOÃO XXIII. Discurso de Sua Santidade Papa João XXIII na abertura solene do SS. Concílio. 11 de outubro de 1962.

$6 \quad$ FISICHELLA, R. La nuova evangelizzazione. Roma: Mondadori, 2011. p. 25.

7 Documento de Puebla. III Conferencia General del Episcopado Latinoamericano. Disponível em: <http://www.celam.org/doc_conferencias/Documento_Conclusivo_Puebla.pdf $>$.

8 Discurso do Papa João Paulo II na abertura da XIX Assembleia do CELAM. Disponível em: <https://w2.vatican.va/content/john-paul-ii/pt/speeches/1983/march/documents/ hf_.p-ii_spe_19830309_assemblea-celam.html>. 
Na Encíclica Redemptoris Missio, de 1990, o papa aponta para alguns destinatários para quem a nova evangelização se dirige: grupos de batizados que perderam o sentido vivo da fé, que não se reconhecem como membros da Igreja e levam uma vida longe de Cristo e do Evangelho, tanto nos países de antiga evangelização, como os da Europa, quanto nos mais jovens, como os da América Latina.

Os pronunciamentos das autoridades eclesiais desde então evidenciam que a exigência da nova evangelização é ordenada pelo contexto cultural e social. A grande fragmentação da sociedade pelo individualismo, a pluralidade de linguagens e comportamentos e a multiplicação de correntes relativistas e niilistas obrigam a uma atenção que se alarga pelo horizonte e um esforço ainda maior do que nos tempos de primeira evangelização. Agora, o homem evangelizado está no epicentro de uma crise que interroga a si mesmo.

O secularismo, o esforço e a prática de viver e construir o mundo como se Deus não existisse, foi se alastrando pelas instituições até que se tornou forma de cultura, mobilizando massas e modificando comportamentos, ao ponto de não mais se perceber seus limites objetivos. O secularismo atingiu seu grau de maior dano quando tocou a existência pessoal humana, afastando o homem do cristianismo:

Secularismo, de fato, significa um distanciamento da religião cristã; esta não tem e não pode ter alguma voz quando se fala de vida privada, pública ou social. A existência pessoal, em suma, se constrói prescindindo do horizonte religioso que é relegado a um simples âmbito privado sem incidir na vida das relações interpessoais, sociais e civis 9 .

A consequência disso é que, para o secularismo, o mundo tornou-se adulto e, não mais necessitando de Deus, anuncia-se dono de uma plena autonomia. O contato com o transcendente deixa de ter lugar na vida pessoal e a contemplação espiritual é lançada fora com uma erupção de reivindicações de liberdades individuais. O cristão é vítima da tentação de conformar-se com o espírito do século ${ }^{10}$ e a fé passa a ser irrelevante na vida prática. Deus, que é substituído pelo homem autorreferencial no centro da vida, torna-se inútil, alguém para se evitar e eliminar.

9 FISICHELLA, p. 29.

10 Cf. Rm 12,3. 
Aqui está o coração motivador da nova evangelização: o homem está fora de seu lugar, pois ele próprio se colocou no posto de Deus. Assim, qual seu lugar dentro da criação? Não há mais, pois já se elevou inclusive a senhor da morte, acarretando na perda do sentido da existência. O homem está desorientado, porquanto se afastou de Deus: “o enigma da existência pessoal não se resolve refutando o mistério, mas escolhendo de colocar-se nele ${ }^{11}$ ". É preciso levar, novamente, Deus ao homem.

Compreende-se a nova evangelização quando se volta para a passagem do Evangelho segundo Lucas: "todos quantos estavam na sinagoga tinham os olhos fixos nele ${ }^{12}$ ". Cristo, o Evangelizador por excelência que traz a salvação, é o rosto de Deus ${ }^{13}$; para chegar até Deus é preciso ter os olhos fixos em Jesus.

A oração do salmista, "a vossa face, ó Senhor, eu a procuro ${ }^{14 ",}$, o esforço da nova evangelização, que busca o rosto de Jesus Cristo para, anunciando-o aos homens, ajuda-los a sair da indiferença. Não pretende o homem ganhar o homem, mas deseja ganhar o homem de Deus para Deus. Seria ineficaz qualquer método se não fosse alicerçado e centrado em Jesus Cristo que é ontem, hoje e para todo o sempre ${ }^{15}$.

Como lembrou Bento XVI ao Collège des Bernardins, "quaerere Deum - buscar a Deus e deixar-se encontrar por Ele: isto, hoje, não é menos necessário do que em tempos passados ${ }^{16 "}$. A procura de Deus fundamenta, ainda hoje, toda a cultura que tange na vida do homem. Assim, é preciso que a nova evangelização encontre sustento em uma reflexão em chave apologética: apresentar-se não para, em primeiro lugar, demonstrar a existência de Deus em postura defensiva e agressiva, mas para mostrar como sem a sua presença o homem acaba por se tornar um estranho si mesmo; para conduzir o homem novamente àquele que acabou sendo para si o grande Desconhecido, a partir de uma nova apresentação da fé da Igreja.

\footnotetext{
11 FISICHELLA, p. 32.

Lc 4,20

Cf. Cl 1,15.

SI 26,8.

$15 \mathrm{Hb} 13,8$.

16 Encontro com o mundo a cultura no Collége des Bernardins. Discurso do Papa Bento XVI. 12 de setembro de 2008. Disponível em: <https://w2.vatican.va/content/benedict-xvi/pt/speeches/2008/september/documents/hf_ben-xvi_spe_20080912_parigi-cultura.html>.
} 


\section{A apologética: restaurar todas as coisas em Cristo}

\subsection{A apologética}

O termo "apologética" pode causar certo incômodo a alguns ao levar a uma caricata visão dos tempos anteriores ao Concílio Vaticano II, nos quais a atividade apologética ficou marcada pelo binômio razão e demonstração. No entanto, apologética aponta, antes de tudo, à apresentação do evento cristão enquanto anúncio de uma novidade. Em um olhar histórico, vemos que os apologetas foram "aqueles antigos escritores cristãos, que se propunham defender a nova religião das pesadas acusações dos pagãos e judeus, e difundir a doutrina cristã em termos adequados à cultura de seu tempo ${ }^{17 \%}$.

Desta forma, observa-se que há na Igreja nascente um movimento apologético sob dois impulsos: no sentido de defender o cristianismo e outro no sentido missionário, que expõe as verdades da fé em linguagem acessível e em categorias de pensamento compreensíveis aos homens da época. Ao nosso contemporâneo, a apologética deve se apresentar não para demonstrar em primeiro lugar a existência de Deus, o que é válido, mas para mostrar como a sua ausência e sua distância faz com que o homem acabe por se tornar um irreconhecível a si mesmo.

A apologética sempre foi necessária para o cristianismo, uma vez que nasceu com ele. O caminho de Emaús é fortemente simbólico neste itinerário do crer: o misterioso viageiro acompanha os dois discípulos que estão desiludidos, sem esperança e com a fé comovida. Jesus os chama de pessoas sem inteligência e lentos no crer, antes de Lucas anunciar que o viajante, partindo de Moisés e dos profetas, "explicava-lhes o que dele se achava dito em todas as Escrituras ${ }^{18}$.

Essa perícope é o primeiro fundamento da apologética. Em primeiro lugar, existe um destinatário: o homem perdido representado pelos dois discípulos. A palavra não é jogada ao vento nem lançada em vão, mas há um receptor carente da mensagem, que já conheceu a verdade, mas não conseguiu, por tantos motivos, nela permanecer e dela viver.

17 BENTO XVI. Os padres da Igreja, de Clemente Romano a Santo Agostinho. São Paulo: Paulus, 2012. p. 21.

18 Lc $24,17$. 
Depois, vemos um encontro, entre o homem sem expectativa e a palavra que pode conferir-lhe sentido. Este encontro acontece a caminho, sem pausas, pois não há tempo para se perder quando se busca a verdade.

Em seguida, o forasteiro misterioso começa a ensinar-lhes; suas palavras inicialmente são de repreensão, sinal da necessidade do não conformismo com o mundo, acompanhadas do precioso ato de explicar racionalmente à luz da fé toda a Escritura que se referia a ele próprio: admoestação e ensino, alerta e proposição, buscando lograr aos olhos obscurecidos dos discípulos a verdade que é ele próprio, sem jamais forçá-los a nada. Logo, aqui Jesus usa de verdadeiro argumento apologético, realizando uma "reflexão crítica que tenta apresentar o conteúdo da fé diante das exigências da razão ${ }^{19}$ ". Uma vez que a apologética nasce com o Evangelho, deve acompanhar a fé até o retorno de Cristo, demonstrando que é possível crer sem renegar a razão.

Neste tocante, a Constituição Dogmática Dei Verbum reafirma a capacidade humana de conhecer a Deus através da razão, fazendo menção à Constituição Dei Filius, do Concílio Vaticano I: "Deus, princípio e fim de todas as coisas, pode ser conhecido com certeza, pela luz natural da razão humana, a partir das coisas criadas; 'pois o invisível dele é divisado, sendo compreendido desde a criação do mundo, por meio do que foi feito' $(\mathrm{Rm} 1,20)^{20 \prime}$ ".

O contato humano com Deus não se dá por duas partes mais ou menos independentes, somente pela fé ou somente pela razão, mas é indivisivelmente uno: a partir do conhecimento natural de Deus se dá um passo ao conhecimento sobrenatural. Segundo a Dei Filius, tanto é necessária conformidade da razão com a fé, que "quis Deus ajuntar ao auxílio interno do Espírito Santo os argumentos externos de sua revelação, isto é, os fatos divinos [...] que, por demonstrarem luminosamente a onipotência e a ciência infinita de Deus, são da revelação divina sinais certíssimos e adaptados à inteligência de todos ${ }^{21}$ ".

A razão, quando iluminada pela fé, de forma pia consegue compreender parte dos mistérios sagrados, uma vez que a inteligência criada não consegue abarcar toda a sabedoria divina. Mas, ainda assim, não

19 FISICHELLA, R. LEXICON - Dicionário Teológico Enciclopédico. São Paulo: Loyola, 2003. p. 44.

21 DENZINGER, H. Compêndio dos símbolos, definições e declarações de fé e moral. São Paulo: Paulinas; Loyola, 2013. n. 3009. 
pode haver desarmonia entre fé e razão, pois é Deus mesmo que infunde a fé e concede razão ao homem. Por conseguinte, compreende-se que a apologética não se funda somente na fé ou somente na razão, mas ciente de que a razão demonstra os alicerces da fé, exige a capacidade de dar razões da própria fé. Não pode haver um novo anúncio da fé se, ao mesmo tempo, não se mostra sua razoabilidade.

A Primeira Carta de Pedro $(3,13-15)$ apresenta um clássico ponto de partida para a formação da apologética. É uma mensagem de encorajamento do apóstolo para a comunidade cristã. Diante das perseguições por causa da fé, os cristãos primitivos são motivados a uma prontidão de espírito, sempre dispostos "a dar razão da vossa esperança a todo aquele que vo-la pede 22 ". Quando Pedro fala em dar razão, está falando de uma apologia, como está na Septuaginta ( $\alpha \pi \mathrm{\pi} \lambda \mathrm{\gamma} \gamma \mathbf{\imath} \alpha \mathrm{v})$, uma defesa, ou como na Vulgata (satisfactionem), uma justificação.

A defesa exortada por Pedro é à esperança. Não é estranho, uma vez que a esperança abarca, de modo implícito, a fé. A esperança, por sua vez, tem centralidade na apologética, logo que, como notou João Paulo II na Ecclesia in Europa, "os nossos dias, com todos os desafios que nos lançam, apresentam-se como um tempo de crise. Muitos homens e mulheres parecem desorientados, incertos, sem esperança; e não poucos cristãos partilham estes estados de alma ${ }^{23}$ ". A nova apologética deve estar capacitada a conceder esperança ao mundo e, além de somente dar esperança, mostrar suas razões. Cabe a ela, na teoria e no testemunho prático, mostrar aquilo que é próprio do cristianismo, a verdade que supera o desespero, de forma nova, de modo ainda mais convincente, sem jamais se esquecer do modo de proceder explicitado por Pedro no versículo 16: com mansidão e respeito.

\subsection{A nova apologética}

A nova apologética não é algo que está nas primeiras fileiras dos posicionamentos eclesiais. No entanto, dois papas deram grande destaque a este tema, sobretudo à sua necessidade aos tempos hodiernos. João Paulo II, no ano de 1982, em discurso aos professores e estudantes da Faculdade de Teologia de Palermo, demonstra que a nova apologética tem

$22 \quad 1 \mathrm{Pd} 13,15$

23 JOÃO PAULO II. Exortação Apostólica Pós-Sinodal Ecclesia in Europa do Santo Padre João Paulo II. 28 de junho de 2003, n. 6. 
por primeiro fundamento a verdade. A Igreja é a Verdade salvífica, pois é o próprio Cristo que se faz presente no hoje da história. Deus revela-se como Verdade, pois é Verdade por essência. Essa missão de salvação, por outro lado, precisa de fiel e corajoso empenho e deve ser garantida e defendida pela Igreja, uma instituição visível e organizada: "A Igreja, por isso, existe unicamente para a Verdade e para a Salvação ${ }^{24 "}$.

O papa santo, ao indicar que os tempos atuais são fustigados pela incredulidade que corrompe as consciências, lembra a urgência e atualidade do estudo sobre a Igreja e sua Verdade que deve ser única e salvífica. Assim alerta:

Hoje, é de primordial importância uma clara e convincente "apologética eclesial", que faça compreender com certeza que a Igreja é de fato, ao mesmo tempo, o "lugar teológico" de base, e também o "lugar hermenêutico", destinado não só a esclarecer as mentes, mas também a confirmá-las naquela que é certamente a Vontade reveladora e redentora do Altíssimo ${ }^{25}$.

Para João Paulo II, a nova apologética, de caráter eclesial, deve ser convincente, esclarecedora e que confirme os homens na verdade, tendo em vista a missão de salvação. Este aspecto da defesa da verdade é o fio condutor da nova apologética para o papa polonês. Segundo ele, a Igreja tem um dom precioso que não pode deixar de transmitir aos fieis. Parte deste dom é a verdade acerca do homem, criado à imagem e semelhança de Deus, que deve ser defendida e difundida neste momento atual da história. Conforme Wojtyla, "a primeira defesa a efetuar é a da dignidade inalienável e do valor da própria vida" ${ }^{26 "}$.

No discurso aos bispos do Canadá, em 1999, quando evidencia o papel da nova apologética, João Paulo II assegura que transmitir a fé católica é um ato de grande responsabilidade diante do Senhor. Essa transmissão, que é evangelizar, significa "anunciar ao mundo uma verdade absoluta e universal; contudo, é nosso dever falar de maneira apropriada e significativa, a fim de tornar as pessoas receptivas desta verdade ${ }^{27 \%}$.

24 JOÃO PAULO II. Discurso do Papa João Paulo II aos professores e estudantes da Faculdade de Teologia de Palermo. 21 de novembro de 1982.

25 Idem.

26 JOÃO PAULO II. Discurso do Papa João Paulo Il aos bispos do Canadá, provenientes da Região Noroeste em Visita "Ad Limina Apostolorum". 30 de outubro de 1999.

27 Idem. 
Uma verdade dita de maneira apropriada: eis o coração da nova apologética. O fato de defini-la como "nova" não pretende qualificar o conteúdo, pois este será sempre Jesus Cristo, mas a condição e as modalidades pelas quais ela é exercida. Quando a verdade atinge o mais profundo do homem, este busca sair da indiferença que ofuscava sua existência. No entanto, é necessário explicar a fé, não somente repeti-la. Conforme João Paulo II, isso quer dizer que,

temos necessidade de uma nova apologética, correspondente às necessidades do hoje, conscientes de que a nossa tarefa não consiste apenas em vencer argumentos, mas em conquistar almas, empenhar-se não unicamente em debates ideológicos, mas em reivindicar e promover o Evangelho ${ }^{28}$.

O papa, no destacado acima, traz o que há de mais necessário para a realização da nova apologética: que corresponda às urgências do homem, não se fixando apenas no assegurar a razoabilidade da fé e a coerência lógica das argumentações racionais, mas atenta ao anunciar o Evangelho, a verdade de Cristo, para a salvação das almas. Neste mesmo discurso, Sua Santidade destaca alguns lugares nos quais esta nova apologética tem por missão acontecer: na catequese, na educação, nas investigações e práticas médicas, entre os legisladores e custódios dos bens públicos, bem como nos meios de comunicação.

O objetivo da nova apologética é o anúncio ao mundo de uma verdade absoluta e universal, que é próprio do evangelizar, mas feito de modo apropriado e significativo, de forma que torne as pessoas receptivas desta verdade. "Jamais devemos perder de vista o fato de que o Evangelho de Jesus Cristo é a verdade à qual todos os homens aspiram, independentemente de quão distantes, resistentes e hostis possam parecer ${ }^{29}$ ".

A nova apologética deve esforçar-se para que os cristãos passem de uma fé rotineira para uma fé vivida conscientemente. No discurso do Papa João Paulo II aos bispos das Antilhas, em 2002, este fato ficou evidente em suas palavras, que podem ser consideradas como basilares na compreensão do novo movimento apologético: "é essencial que nas vossas Igrejas particulares se desenvolva uma renovada apologética para o vosso povo, a fim de que ele possa entender aquilo que a Igreja

\footnotetext{
28 Ibdem.
}

29 Ibdem. 
ensina e, deste modo, ser capaz de explicar a razão da sua esperança [a quem lhe perguntar] $]^{30 "}$.

Para os católicos, ainda segundo o pontífice, é essencial que conheçam o conteúdo do ensinamento da Igreja, compreendendo o magistério eclesial e tomando consciência através do contato pessoal com o seu poder libertador. Diante de um mundo em que os homens vivem sob grande pressão cultural e ideológica das mídias e de atitudes agressivas por parte de muitas seitas, a não compreensão pode levar a uma escassez da energia espiritual necessária para a vida de batizado.

Em 2008, o Papa Bento XVI escreveu linhas fundamentais para o desenvolvimento da nova apologética. Respondendo aos bispos americanos em sua visita aos Estados Unidos, o papa lembrou que, em uma sociedade altamente secularizada e que valoriza a liberdade pessoal,

a Igreja deve promover a todos os níveis os seus ensinamentos na catequese, na pregação, na instrução no seminário e na universidade uma apologética destinada a afirmar a verdade da revelação cristã, a harmonia entre fé e razão, e uma sadia compreensão da liberdade, vista em termos positivos como libertação tanto dos limites do pecado como para uma vida autêntica e plena ${ }^{31}$.

Assim sendo, pode-se compreender que a nova apologética ocupa um duplo lugar na teologia: primeiro, na teologia fundamental, onde contribui para o fundamento da busca teológica, e na pastoral, em que a teologia está unida à cultura. Por isso, o intento da nova apologética é perene: a pregação e o ensino do Evangelho como um modo de vida integral, que concede uma resposta bela e autêntica, racional e prática, aos problemas do homem concreto. O desafio é reencontrar a visão católica da realidade e propô-la de modo envolvedor e direto a uma sociedade que se acostumou a cultuar o nada. Como lembrou Bento XVI, é preciso "falar ao coração", pois os homens continuam a ter "sede de autenticidade, bondade e de verdade".

\footnotetext{
30 JOÃO PAULO II. Discurso do Santo Padre João Paulo Il aos Bispos das Antilhas em visita "Ad Limina Apostolorum". 07 de maio de 2002.

31 BENTO XVI. Respostas do Papa Bento XVI às perguntas dos Bispos Americanos. 16 de abril de 2008.
} 


\subsection{Caminhos da nova apologética}

Diante de todo o exposto, a questão do "como" é inevitável, de forma que sempre surge como desafiadora. Tal dever, de expor uma nova apologética e a forma como se apresenta, exige uma grande coerência entre fé e vida por parte de quem oferece as razões do seu crer. Em 1999, João Paulo $\mathrm{II}^{32}$ apontou quatro qualidades indispensáveis no diálogo dos bispos para com os seus coevos: clareza, humanidade, confiança e prudência.

O empenho nessas qualidades caracteriza o modo de proceder de uma nova apologética: a clareza para explicar a verdade da Igreja; a humanidade que compreende os anseios das pessoas; a confiança de que Jesus Cristo é a verdade e a prudência para agir com sabedoria, bom senso e coragem.

A partir disso, prevê-se que a nova apologética, em primeiro lugar, deve deter sua atenção sobre a beleza da criação de Deus, concentrando-se no mistério e na beleza do culto católico, pois a liturgia é o "centro vivificante da Igreja e centro da vida cristã" ${ }^{33}$, a principal ação pela qual a Igreja manifesta na realidade sensível a sua mediação de Cristo que se revela. Valoriza-se assim uma visão sacramental do mundo, de modo que permite ao homem reconhecer e apreciar a graça da criação como prefiguração dos novos céus e da nova terra ${ }^{34}$.

Desde a origem da Igreja existiu a presença da ação litúrgica que, ao anunciar o Evangelho, o fazia sinal visível de salvação. Pela liturgia, os primeiros cristãos celebravam Cristo presente no meio da comunidade, de forma que anúncio e liturgia complementavam-se. A presença de Cristo é força de transformação para o homem, que encontra na liturgia espaço vital de realização do anúncio, pois nela Cristo "se faz constantemente contemporâneo a nós de modo sempre novo e entra na nossa vida ${ }^{35}$ ".

No cotidiano, onde se desenvolve a pastoral, é possível compreender a necessidade que o mundo possui de sinais que conduzam ao mistério. A liturgia proporciona a imersão do homem no mistério,

32 JOÃO PAULO II. Discurso do Papa João Paulo Il aos bispos do Canadá, provenientes da Região Noroeste em Visita "Ad Limina Apostolorum". 30 de outubro de 1999.

33 RATZINGER, J. Opera Omnia. Teologia Della Liturgia. Vol. XI. Città del Vaticano: Libreria Editrice Vaticana, 2011. p. 25.

$34 \quad 2 P d 3,13$.

35 RATZINGER, p. 25. 
libertando-o da esfera do problema. O filósofo Gabriel Marcel evidenciou esta polaridade, notando que quanto mais o homem se deixa envolver pelo mistério, mais se compromete consigo mesmo, transcendendo a objetividade da imanência e se abrindo à transcendência: "o mistério é alguma coisa a que estou ligado, não parcialmente por algum aspecto determinado e especializado, mas inteiramente, enquanto realizo uma unidade que por definição nunca pode apreender-se a si própria e só pode ser objeto de criação e de fé é $^{36}$ ".

A vida litúrgica da Igreja hoje oferece uma gama de possibilidades, desde celebrações de batismos até exéquias, para comunicar a mensagem que de outra forma não seria ouvida: “quantos 'indiferentes' à religião participam a estas celebrações e quantas pessoas que estão em busca de uma genuína espiritualidade estão presentes! A palavra do sacerdote em tais circunstâncias deveria ser capaz de provocar a pergunta pelo sentido da vida ${ }^{37}$.

Celebrar a liturgia não é tomar parte de um mero ritualismo diverso à vida de cada dia do homem, isso corresponderia ao oposto do mistério, mas é oferecer a esse mesmo homem uma resposta ao seu questionamento de sentido que tantas vezes se deparou com lugares vazios. Sinais e orações são repletos de significado, pois levam o ser humano ao centro de sua existência no voltar-se do Mediador à direção do homem.

Hoje em dia as novas gerações de cristãos já não mais sabem o que quer dizer, por exemplo, céu, salvação, beatitude. E não sabendo o que é cada coisa, colocam-se como expectadores fora da anelação daquilo que Deus reservou para os que o amam. Não se almeja o que não se conhece, não se alcança aquilo do qual não se tem consciência. A nova apologética não precisa problematizar a fé, demonstrando a existência dessas verdades, mas necessita mostrar a possibilidade de alcançá-las e o meio para tal.

Em seguida, a nova apologética deve valer-se do testemunho dos crentes que, através da justiça e da caridade, colocam em prática sua fé como seguidores de Jesus Cristo. A credibilidade do novo movimento apologético subsiste na vivência do serviço como primado a se desenvolver, sem o desejo de ser maior que o outro, mas cônscio da responsabilidade a ser exercida.

36 MARCEL, G. Os homens contra o homem. Porto: Editora Educação Nacional, [S.d.]. p. 81.

37 FISICHELLA, R. La nuova evangelizzazione. Roma: Mondadori, 2011, p. 63. 
Segundo a Carta aos Hebreus, o primeiro dever dos que zelam pelas almas é o anúncio da Palavra de Deus ${ }^{38}$. A pregação abre oportunidade para a tomada de conhecimento, que por sua vez leva à adesão da fé ${ }^{39}$. No entanto, o modo de vida de quem anuncia provoca um 'imitar na fé' ao que ouve o anúncio. A Carta aos Hebreus afirma tal verdade, mostrando que após o anúncio da Palavra de Deus pelos dirigentes, é preciso considerar "como terminou a vida deles, e imitai-lhes a fét ${ }^{40}$ ".

A eficácia da nova apologética não está em muita pregação, mas na visível comprovação de fé que dá credibilidade ao que se prega. $\mathrm{O}$ testemunho da caridade é o maior sinal que a Igreja pode oferecer ao mundo de seu seguimento de Cristo, uma vez que constitui o próprio coração do seu anúncio: "pela fé se compreende como Deus ama; na caridade se torna evidente como os cristãos são fiéis à sua palavra ${ }^{41}$ ". Fisichella chama de "olhar estrábico" a incoerência do não testemunho: "se os olhos estão fixos em Jesus Cristo, devem estar também sobre quantos tem fome e sede, são estrangeiros, nus, doentes e encarcerados, pois neles ele é visível ${ }^{42}$ ".

Outro ponto importante do acontecer da nova apologética é o diálogo da fé com a ciência e a tecnologia, adentrando no mundo da cultura. Alguns cientistas falam de sua fé de modo pessoal, no entanto, o aspecto público da ciência e da tecnologia é determinadamente agnóstico. Neste campo fértil e necessário de se estabelecer uma ponte que leve o homem à verdade, a teologia - e a nova apologética lhe é parte integrante - tem como dever "escutar as solicitações das várias culturas, para permeá-las depois, por meio de uma coerente conceitualização, com o conteúdo da fét ${ }^{43}$ ".

Uma vez que a apologética quer dar razões da própria fé, precisa encarar de modo novo a cultura contemporânea que parece cada vez mais contradizente com o Evangelho e seus valores, proporcionando essa conceitualização indicada por João Paulo II na Fides et Ratio. Em um desenvolvimento sempre rápido da ciência, que apresenta uma segmentação em especializações de conhecimento, a nova apologética pode agregar diversos saberes através da fé.

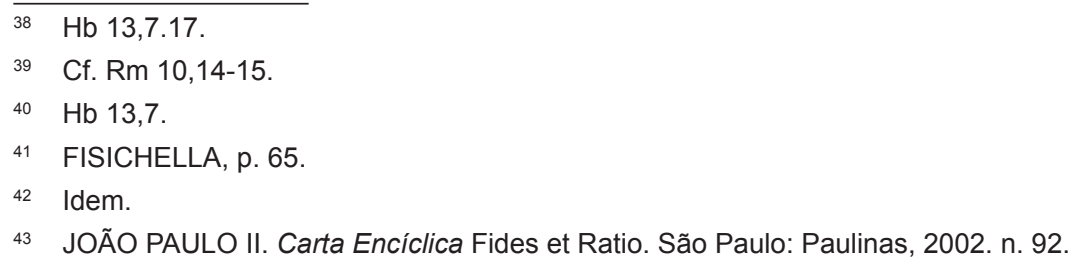


A encíclica do papa polonês afirma ainda que a teologia contemporânea possui uma dupla tarefa: "renovar as suas metodologias, tendo em vista um serviço mais eficaz à evangelização" e por outro lado "manter o olhar fixo sobre a verdade última que lhe foi confiada por meio da Revelação, não se contentando nem se detendo em etapas intermediárias ${ }^{44}$ ".

A conceitualização proposta por João Paulo II passa por uma interdisciplinaridade quando da necessidade de dar respostas aos mais diversos problemas contemporâneos, exigindo um trabalho comum. $\mathrm{O}$ teólogo não se deparará somente com problemas teológicos, também com questões filosóficas, históricas, científicas e sociais. A fé será a luz que guiará o saber comum a uma solução, sem abdicar da verdade revelada ou cair no relativismo. Para tal, é preciso uma sólida formação teológica, seja aos clérigos como aos leigos, para que a fé não seja somente forma, mas um conhecido, razoável e possível conteúdo.

O cardeal Francis George afirma que o ingresso da fé no mundo da ciência e da cultura pode começar através das universidades católicas: "A implementação da Ex Corde Ecclesiae é um primeiro passo necessário a uma compreensão renovada de como a nossa fé na verdade apoia e sustenta as instituições de ensino superior católico ${ }^{45}$ ". A nova apologética, conforme o cardeal, deve ter início com a mudança dentro da própria casa, deve ter o trabalho de dizer a verdade começando nas homilias, na juventude, nos programas de catequese de adultos e na educação em instituições católicas.

O dever do novo apologeta será, portanto, procurar novos métodos para conduzir todos à salvação, sem esquecer que seu trabalho está ligado à fé, sendo fiel à pureza dessa mesma fé, para que a Verdade, autoridade universal, possa ser anunciada, conhecida e aderida.

\subsection{Verdade e caridade}

A fim de concluir esta exposição sobre a nova apologética, é preciso voltar um último olhar a uma passagem do Evangelho de João que condensa todo o empenho desse movimento: o relato da mulher surpreendida em adultério ${ }^{46}$. A maneira como a narração coloca a dis-

\footnotetext{
44 Idem.

45 GEORGE, Francis. A New Evangelization in a New Millennium: A Call for a New Apologetics. In: Lay Witness Magazine, May 2000.

46 Jo 8,1-11.
} 
posição de Jesus para com a mulher e seus acusadores é perfeitamente instrutiva. Cristo, que é Deus, conhece os corações dos homens e, ao invés de deixar-se levar pelo legalismo, soube colocar cada coisa em seu lugar conforme a ótica de seu olhar que é misericordioso, que julga conforme a verdade na caridade.

Essa passagem é a chave da nova apologética, concordando verdade e caridade. Verdade, pois Jesus dá a retribuição aos acusadores da mulher, que estavam prontos a castigá-la pelo adultério, não por que erraram no objeto do pecado da pessoa, inclusive se baseavam na antiga lei, mas porque lhes faltou respeito à dignidade da pessoa. Jesus então coloca diante dos olhos enfurecidos de cada um deles os pecados que faustosamente escondiam.

Ao mesmo tempo, reveste aquela que era considerada a maior em indignidade com o manto da caridade, preservando-a do ódio e da injustiça, dando a ela a chance da nova vida. Ainda assim, não falta com a verdade para com a mulher, confirmando o seu pecado: "Vai, e de agora em diante não peques mais". Concomitantemente, como consequência do amor dado por ele, Jesus convida a mulher à conversão, a voltar-se para Deus, a encontrar nEle a vida e a verdade que faz de cada um livre para amar.

Essa perícope ilumina a Igreja a cumprir de forma mais perfeita sua missão congregando a verdade e a caridade. Isso demonstra que a Igreja é católica e apostólica: Católica, pois estende seus braços a todos, de forma especial ao mais pecador e menos digno. Apostólica, pois a Igreja estende os braços levando a fé que vem dos apóstolos, tesouro a ser guardado ${ }^{47}$, sem violar a dignidade do homem, feito à imagem e semelhança de Deus.

Explicita o texto sagrado o espírito de humanidade que deve respirar o novo movimento apologético, uma humanidade que, por um lado, não se faz apressada em ver na pessoa sua má fé, mas que compreende a grande interrogação que há dentro de cada um, e por outro lado, não recorre a um sentimentalismo de aparência avulso da verdade, mas permanece no fato de que "o verdadeiro amor e compaixão podem apresentar reivindicações radicais, precisamente porque são inseparáveis da única verdade que liberta" ${ }^{48}$ ".

$47 \quad 1 \mathrm{Tm} 6,20$.

48 JOÃO PAULO II. Discurso do Papa João Paulo ll aos bispos do Canadá, provenientes da Região Noroeste em Visita "Ad Limina Apostolorum". 30 de outubro de 1999. 
Sempre haverá no coração da nova apologética um apelo à conversão, realizado com amor para com aquele que ainda não se doou totalmente a Cristo, pois de nada vale ganhar o argumento e perder a alma. Em meio a tantos ventos contrários, somente uma Igreja unida em torno de Cristo e firme na fé pode oferecer o remédio aos dois pecados presentes em João 8,1-11. Se lá havia o adultério e a presunção, a Igreja oferece a verdade e a caridade.

\section{Considerações finais}

Aquilo que a Igreja anuncia não é uma verdade construída pelo homem, mas é revelada por Cristo como um presente sem valor comparável. Cada batizado é levado a anunciar esta verdade e, com caridade, cooperar na obra de salvação. Ser um evangelizador não constitui um privilégio, mas um grande compromisso que provém da fé.

O mundo de hoje tem necessidade de pessoas que corajosamente anunciem que é Cristo que preenche os vazios que existem dentro do homem, pois é ele quem ensina a arte de viver, a felicidade verdadeira. Para colaborar nisto, a Igreja católica possui uma rica herança espiritual e cultural, podendo tudo dispor para a nova evangelização.

Em primeiro lugar, foi salientada a importância e o papel da nova evangelização em um contexto de constantes mudanças sociais, culturais e espirituais, sobretudo marcado pelo desenvolvimento da secularização, que deixa uma profunda marca em todos os países, especialmente de tradição cristã. A nova evangelização, como se notou, requer a capacidade de dar razões da própria fé, anunciando Jesus Cristo como único caminho de salvação.

Em seguida, entrando na estrada da apologética, buscou-se contemplar um panorama histórico para compreender o que é o novo movimento apologético, bem como as inspirações bíblicas, teológicas e pastorais. A partir desses aspectos, foi possível tomar ciência da importância de se empreender a nova apologética analisando sobretudo os pronunciamentos dos papas João Paulo II e Bento XVI e os modos como proceder na sua prática aplicação.

O presente escrito faz perceber como são importantes e necessários os novos evangelizadores que, em grande número, poderão fazer acontecer uma transformação da qual tanto precisa o mundo de hoje, e quão urgente são os novos apologetas, capazes de, na verdade e na caridade, construírem a civilização do amor. 
Da mesma forma, se pode notar a necessidade de levar o conteúdo da fé a todos os fiéis, pois sem conteúdo não pode acontecer uma nova evangelização. Antes mesmo de qualquer reforma institucional, é necessário apresentar plenamente o Credo, aquele rezado nas missas, mas esquecido em seu conteúdo. A nova apologética, que não possui a mesma forma da apologética tradicional, mas que busca antes de tudo o sentido para a existência do ser humano, se mostra indispensável e urgente, e para que ela bem aconteça jamais poderá faltar um autêntico testemunho de vida cristão por parte do evangelizador.

Deve-se, à guisa de conclusão, recordar que o homem é um ser que espera razões para viver, para crer, para esperar e para amar. Esperar a resposta do por que de cada coisa da vida é buscar um caminho que leva a matar a sede que há dentro do próprio coração, sede de ciência, sede de sabedoria, sede, enfim, de Deus. A nova apologética, portanto, deve saciar o homem indiferente, mas para que isto aconteça é necessário colocar-se sob o primado da graça, que concede a cada um a presença viva do Espírito Santo e transforma os corações, acolhendo o anúncio da salvação.

\section{Referências bibliográficas}

BENTO XVI. Carta Apostólica em forma de Motu Proprio "Ubicumque et semper". 21 de setembro de 2010.

. Os padres da Igreja, de Clemente Romano a Santo Agostinho. São Paulo: Paulus, 2012.

. Respostas do Papa Bento XVI às perguntas dos Bispos Americanos. 16 de abril de 2008.

CELAM. Discurso do Papa João Paulo II na abertura da XIX Assembleia do CELAM. Disponível em: $<\mathrm{https}: / / \mathrm{w} 2$.vatican.va/content/john-paul-ii/ pt/speeches/1983/march/documents/hf_jp-ii_spe_19830309_assemblea-celam.html>.

CHESTERTON, G. K. Tremendas Trivialidades. Campinas: CEDET, 2012.

CONFERENCIA GENERAL DEL EPISCOPADO LATINOAMERICANO. Documento de Puebla. Disponível em: $<$ http://www.celam.org/ doc_conferencias/Documento_Conclusivo_Puebla.pdf $>$. 
COMPENDIO DO VATICANO II. Constituições, Decretos e Declarações. 31. ed.. Petrópolis: Vozes, 1996. Constituição Dogmática Dei Verbum, n. 6.

DENZINGER, H. Compêndio dos símbolos, definições e declarações de fé e moral. São Paulo: Paulinas; Loyola, 2013. n. 3009.

FISICHELLA, R. La nuova evangelizzazione. Roma: Mondadori, 2011. GEORGE, Francis. A New Evangelization in a New Millennium: A Call for a New Apologetics. Lay Witness Magazine, May 2000.

JOÃO PAULO II. Carta Encíclica Fides et Ratio. São Paulo: Paulinas, 2002. n. 92.

. Discurso do Papa João Paulo II aos bispos do Canadá, provenientes da Região Noroeste em Visita "Ad Limina Apostolorum”. 30 de outubro de 1999.

. Discurso do Papa João Paulo II aos professores e estudantes da Faculdade de Teologia de Palermo. 21 de novembro de 1982.

. Discurso do Santo Padre João Paulo II aos Bispos das Antilhas em visita "Ad Limina Apostolorum", 07 de maio de 2002.

. Exortação Apostólica Pós-Sinodal Ecclesia in Europa do Santo Padre João Paulo II. 28 de junho de 2003, n. 6.

JOÃO XXIII. Discurso de Sua Santidade Papa João XXIII na abertura solene do SS. Concílio. 11 de outubro de 1962.

MARCEL, G. Os homens contra o homem. Porto: Editora Educação Nacional, [S.d.].

PAPA BENTO XVI. Encontro com o mundo a cultura no Collége des Bernardins. 12 de setembro de 2008. Disponível em: $<$ https://w2.vatican. $\mathrm{va} /$ content/benedict-xvi/pt/speeches/2008/september/documents/hf_ben-xvi_spe_20080912_parigi-cultura.html $>$.

RATZINGER, J. Opera Omnia. Teologia Della Liturgia. Vol. XI. Città del Vaticano: Libreria Editrice Vaticana, 2011. 